\title{
ANÁLISE DE IMAGEM DE CAMPANHA OFICIAL CONTRA HIV/AIDS NO BRASIL: UM ESTUDO QUALITATIVO
}

\author{
IMAGE ANALYSIS OF AN OFFICIAL CAMPAIGN \\ AGAINST HIV/AIDS IN BRAZIL: A QUALITATIVE STUDY
}

\section{ANÁLISIS DE IMÁGENES DE UNA CAMPAÑA OFICIAL CONTRA EL VIH/SIDA EN BRASIL: UN ESTUDIO CUALITATIVO}

\author{
João Cruz Neto ${ }^{1}$ \\ Joseph Dimas de Oliveira ${ }^{2}$
}

Como citar este artigo: Cruz Neto J, Oliveira JD. Análise de imagem de campanha oficial contra HIV/AIDS no Brasil: um estudo qualitativo. Rev baiana enferm. 2020;34:e38224.

Objetivo: analisar a imagem dos cartazes veiculados pelo Ministério da Saúde do governo brasileiro na campanha em combate a AIDS no carnaval, à luz da perspectiva dos estudos de gênero. Método: estudo qualitativo e de análise de imagem e em mídias sociais. Realizou-se análise dos cartazes da campanha oficial contra AIDS/HIV no Carnaval de 2018, com base nos passos da análise de imagem de Penn. Resultados: no inventário denotativo identificaram-se fotografias e ilustrações de figuras humanas, roupas, adereços de carnaval e frases. As fotografias ocupam lugar central e as ilustrações ocupam o entorno da imagem. As frases ocupam a parte central e inferior da imagem e traz mensagens verticalizadas. Os temas abordados foram a prevenção do Vírus da Imunodeficiência Humana. Conclusão: existe uma ambiguidade de discursos em que coexistem uma linguagem horizontalizada embasada na estratégia da prevenção combinada e uma linguagem verticalizada expressa nos verbos no imperativo.

Descritores: HIV. Governo. Pôster. Minorias sexuais e de gênero. Educação em saúde.

Objective: to analyze the image of the posters published by the Brazilian Ministry of Health in the campaign to fight AIDS in carnival, in the light of the perspective of gender studies. Method: qualitative study of image and social media analysis. The posters of the official campaign against AIDS/HIV were performed during Carnival of 2018, based on the steps of Penn's image analysis. Results: photographs and illustrations of human figures, clothes, carnival props and phrases were identified in the denotative inventory. The photographs occupy a central place and the illustrations occupy the surroundings of the image. Sentences occupy the center and bottom of the image and bring verticaloriented messages. The topics addressed were the prevention of human immunodeficiency virus. Conclusion: there is an ambiguity of discourses, in which a horizontal-oriented language based on the strategy of combined prevention coexists with a vertical-oriented language expressed in verbs in the imperative.

Descriptors: HIV. Government. Poster. Sexual and gender minorities. Health education.

Objetivo: analizar la imagen de los cartelespublicados por el Ministerio de Salud del Gobierno brasileño en la campaña de lucha contra el SIDA en carnaval, a la luz de la perspectiva de los estudios de género. Método: estudio cualitativo $y$ análisis de imágenes y en redes sociales. Los carteles de la campaña oficial contra el SIDA/VIH se realizaron en

\footnotetext{
Estudante de Enfermagem. Universidade Regional do Cariri. Crato, Ceará, Brasil. enfjcncruz@gmail.com. http://orcid.org/0000-0002-0972-2988.

Enfermeiro. Doutor em Enfermagem. Professor Assistente da Universidade Regional do Cariri. Crato, Ceará, Brasil.

http://orcid.org/0000-000 I-8105-4286.
} 
Carnaval 2018, basándose en los pasos del análisis de imagen de Penn. Resultados: fotografías e ilustraciones de figuras humanas, ropa, accesorios de carnaval y frases fueron identificados en el inventario denotativo. Las fotografias ocupan un lugar central y las ilustraciones ocupan el entorno de la imagen. Las oraciones ocupan el centro y la parte inferior de la imagen y traen mensajes verticales. Los temas abordados fueron la prevención del virus de la inmunodeficiencia humana. Conclusión: existe una ambigüedad de discursos en los que coexiste un lenguaje horizontal basado en la estrategia de prevención combinada y un lenguaje vertical expresado en verbos en el imperativo.

Descriptores: VIH. Gobierno. Póster. Minorias sexuales y de género. Educación para la salud.

\section{Introdução}

A Síndrome da Imunodeficiência Adquirida (AIDS) corresponde à infecção pelo vírus da imunodeficiência humana (HIV), cuja transmissão pode ocorrer entre as pessoas através de relações sexuais desprotegidas, pelo compartilhamento de seringas contaminadas, por transmissão vertical (de mãe para filho/a durante a gravidez), pela amamentação, e/ou quando não são realizadas as devidas medidas de prevenção ${ }^{(1)}$. Em 2019, dentre os homens infectados pelo HIV, houve predomínio da exposição a homo/bissexuais (40,3\%), superando o número de heterossexuais $(38,7 \%)$ e da exposição a drogas injetáveis e compartilhamento de seringas e agulhas ${ }^{(1)}$.

O conhecimento dos métodos de prevenção torna-se importante para sedimentar as ações de promoção da saúde entre os diferentes estratos sociais, de gênero, de orientação sexual e faixa etária, por exemplo. Os órgãos governamentais, ao utilizarem-se da publicidade e dos seus meios (cartaz, panfletos, outdoors, vídeos), atuam na disseminação de conhecimentos de saúde e podem atuar como promotores de saúde ${ }^{(2)}$. Nesse sentido, tem-se a importância da propaganda publicitária para incentivar, divulgar, informar e educar em tópicos relativos ao cuidado em saúde, utilizando-se de textos escritos e textos de imagem ${ }^{(3)}$. Assim, para além de ser publicitária, a campanha governamental precisa ser educativa em saúde mediante textos escritos e de imagem.

O texto de imagem é um projeto visual que contempla uma relação distribuída entre cores, temas verbais e não verbais. O texto de imagem deriva de uma imagem, e esta, por sua vez, pode ser expressiva ou comunicativa. Dessa forma, é possível admitir que uma imagem sempre se constitui em uma mensagem para o outro, mesmo quando este outro somos nós mesmos ${ }^{(4)}$. Por isso, cabe a utilização de recursos que explorem o sentido e deem significado às visões sobre um determinado plano que projeta a imagem.

No Brasil, o Programa Nacional de Combate a AIDS destina-se a ações de combate à doença e iniciou as atividades em 1988. Em 1999, surge a Campanha de Prevenção ao HIV/AIDS no Carnaval que, em sua ideia inicial, foi direcionada para toda a população no intuito de possibilitar uma mensagem objetiva em relação aos métodos de prevenção ${ }^{(5)}$. Durante a trajetória das campanhas de carnaval, os focos foram utilizados para a prevenção e conscientização direcionado por vezes para a figura feminina, as mulheres maiores de 50 anos, os gays e os jovens ${ }^{(6)}$.

No entanto, a publicidade ministerial, ao promover conhecimento e divulgar condutas de promoção da saúde, restringiu-se a apenas informar a utilização do preservativo masculino, deixando lacunas, como o modo de vida, a detecção e o acompanhamento dos $\operatorname{casos}^{(6)}$. Em 2012, a capa da campanha ministerial apresentou como cartaz oficial dois jovens gays abraçados, que, inicialmente, foi vetado pela Câmara dos Deputados $^{(5)}$, constituindo-se assim, uma ação contrária às ações de promoção da saúde que são inclusivas, já que devem destinar-se a todas as pessoas.

No carnaval de 2018, o Ministério da Saúde adotou e divulgou o método da Prevenção 
Combinada nas imagens oficiais da campanha de prevenção ao HIV/AIDS ${ }^{(5-6)}$. A Prevenção Combinada é uma estratégia que engloba o uso simultâneo de diferentes abordagens de prevenção (biomédica, comportamental e socioestrutural) aplicadas em múltiplos níveis (individual, nas parcerias/relacionamentos, comunitário, social), para responder às necessidades específicas de determinados públicos e de determinadas formas de transmissão do $\mathrm{HIV}^{(7)}$.

Por isso, a associação de conforto ou desconforto produzida através da infecção pelo vírus impacta o indivíduo e suas relações, de forma a atingir diretamente a sua visão de mundo e sua conduta frente ao mesmo ${ }^{(8-9)}$. A estratégia ainda permite a identificação e tratamento do HIV sob diferentes formas. Algumas estratégias baseiam-se no diagnóstico e tratamento precoce de pessoas com HIV ou infecções sexualmente transmissíveis (IST) ou daqueles que já convivem com a doença, como também o uso de preservativo masculino, feminino e gel, distribuídos gratuitamente, na testagem regular para o HIV, IST e Hepatites Virais (HV), profilaxia pré-exposição, profilaxia pós-exposição, prevenção da transmissão vertical e a imunização para o vírus da hepatite B (HBV) e papiloma vírus humano (HPV) ${ }^{(8)}$.

Diante do exposto, surge a necessidade de explorar as características das campanhas oficiais do Governo Federal quanto à veiculação em mídia social das ações de promoção da saúde, tendo em vista disponibilizar maior quantidade de informações dos métodos de prevenção combinada, bem como evidenciar as relações de poder existentes entre os grupos que possuem o domínio da informação.

Com isso, surgiu o questionamento: Quais os conteúdos veiculados em uma campanha oficial de carnaval em textos escritos e de imagem sobre a prevenção do HIV?

O objetivo do estudo foi analisar as imagem dos cartazes veiculados pelo Ministério da Saúde do governo brasileiro na campanha em combate a AIDS no carnaval, à luz da perspectiva dos estudos de gênero.

\section{Método}

Trata-se de estudo qualitativo de análise de imagem e em mídia social realizado pela análise de cartazes do Programa Nacional de Combate a AIDS. A análise de imagem compreende a seleção e análise dos textos escritos e de imagem, com o objetivo de investigar os elementos de significação e, com isso, identificar as particularidades que a compõe, isto é, articular os textos (escritos e de imagem) ao contexto sociocultural ${ }^{(4)}$.

A análise ocorreu entre maio e novembro de 2018. A amostra compreende os cartazes da campanha de combate a AIDS no carnaval de 2018, publicadas na mídia social Instagram. A justificativa para esse recorte temporal foi a adoção da estratégia da prevenção combinada, recomendada pelo Programa Conjunto das $\mathrm{Na}$ ções Unidas sobre HIV/AIDS (UNAIDS) em consonância com a Organização Mundial da Saúde (OMS) desde 2010. Para a coleta de dados foi utilizado um formulário com todas as fases relativas à análise de imagem. A análise de imagem é feita em cinco estágios; no primeiro, ocorre a seleção do corpus textual. No presente estudo, o corpus textual compreendeu os cartazes oficiais do Ministério da Saúde em 2018. No segundo estágio, intitulado fase denotativa, distinguem-se os componentes existentes, relatando os tipos de imagens empregadas: desenho/s, ilustração/ões, fotografia/s ou pintura/s ${ }^{(4)}$.

No terceiro estágio, denominado fase conotativa, ocorre o reconhecimento das imagens caracterizadas (animais, figuras humanas ou objetos) e dos signos linguísticos (frases, palavras, sentenças e hashtags), para interpretar o conteúdo da mensagem transmitida e a quem se destina. No quarto estágio, o analista de imagem reconhece os temas apresentados, e, no quinto estágio, o princípio do conhecimento difundido e/ou o mito que embasa a construção sociocultural da imagem ${ }^{(4)}$. Os dados foram discutidos à luz de conceitos de teóricas feministas, como Jean Scott, e conceitos relativos à constituição do Sistema Único de Saúde (SUS), como integralidade, equidade e universalidade. 
No caso desta pesquisa, a análise de conteúdo ocorreu com base nos temas identificados na última fase de análise que geraram as categorias de análise $^{(4)}$. A análise de imagem não pressupõe a submissão ao Comitê de Ética em Pesquisa (CEP) pelo fato de analisar dados (cartazes) disponíveis publicamente em mídia social (Instagram).

\section{Resultados}

As imagens analisadas foram sete cartazes oficiais divulgados pelo Ministério da Saúde, Brasil, em 2018, conforme observado no Mosaico 1.

Mosaico 1 - Cartazes oficiais da campanha do Ministério da Saúde, Brasil - 2018

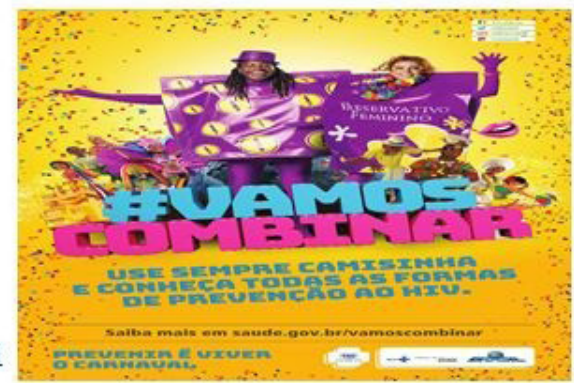

2
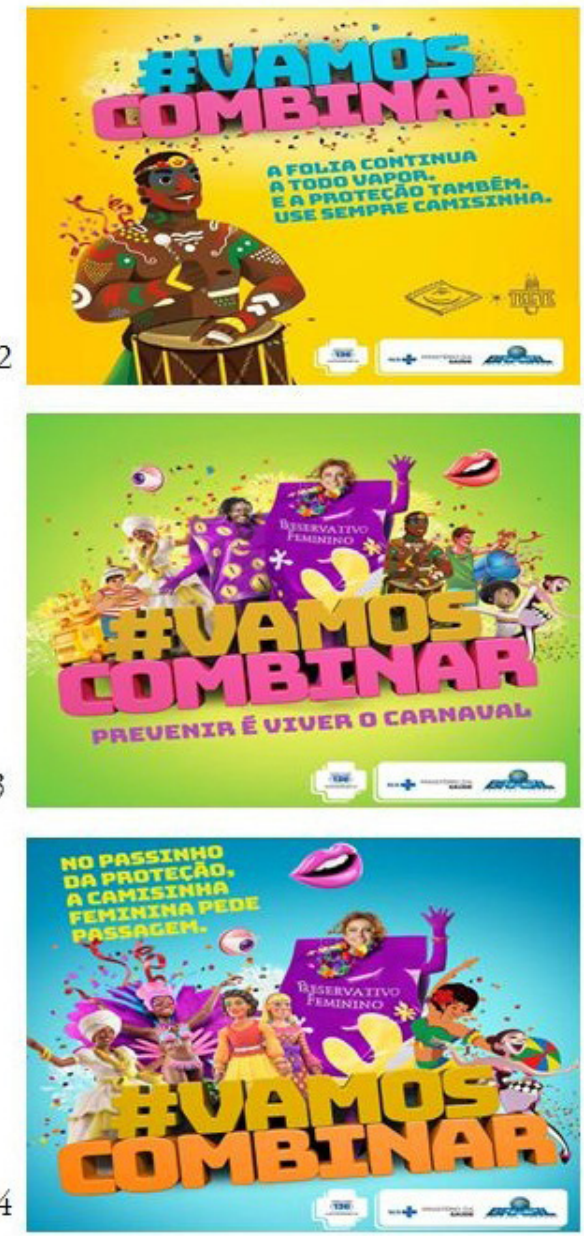
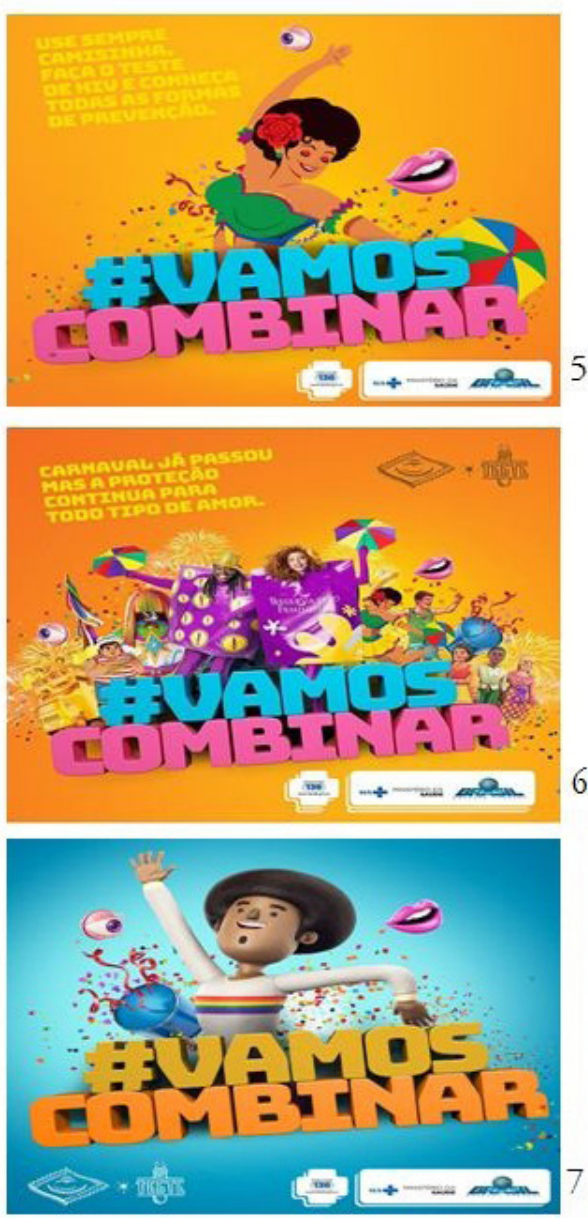

Fonte: Elaboração própria. 
A análise das imagens permitiu a construção dos elementos significantes adaptando as particularidades que os compõem e articulando o texto escrito ao contexto sociocultural (Quadro 1).

Quadro 1 - Fase conotativa e denotativa dos cartazes da campanha em combate a AIDS

\begin{tabular}{|c|c|c|}
\hline № & Fase denotativa & Fase conotativa \\
\hline 1 & $\begin{array}{l}\text { Uma Fotografia (ocupa lugar central } \\
\text { no cartaz e evidencia o gênero } \\
\text { masculino e o feminino). } \\
\text { Uma Ilustração (ocupa lugar central, } \\
\text { entretanto estão no entorno da } \\
\text { fotografia). }\end{array}$ & $\begin{array}{l}\text { Uma fotografia com duas figuras humanas; nove } \\
\text { ilustrações de figuras humanas; uma ilustração de } \\
\text { globo festivo, um trio elétrico e uma figura com } \\
\text { formato de lábios e dentes e confetes nas bordas. }\end{array}$ \\
\hline 2 & $\begin{array}{l}\text { Uma Ilustração (ocupa posição lateral } \\
\text { esquerda na imagem). }\end{array}$ & $\begin{array}{l}\text { Só há uma ilustração do gênero masculino } \\
\text { representando matrizes africanas na imagem; } \\
\text { um tambor. }\end{array}$ \\
\hline 3 & $\begin{array}{l}\text { Uma Fotografia (ocupa lugar central } \\
\text { no cartaz e evidencia o gênero } \\
\text { masculino e o feminino). } \\
\text { Uma Ilustração (ocupa lugar central, } \\
\text { entretanto está no entorno da } \\
\text { fotografia). }\end{array}$ & $\begin{array}{l}\text { Uma fotografia no centro da imagem com duas figuras } \\
\text { humanas; seis ilustrações de figuras humanas; um trio } \\
\text { elétrico; uma figura no formato de olho e uma figura } \\
\text { no formato de lábios e dentes, além de confetes nas } \\
\text { bordas da imagem. }\end{array}$ \\
\hline 4 & $\begin{array}{l}\text { Uma Fotografia (ocupa lugar central } \\
\text { no cartaz e evidencia o gênero } \\
\text { feminino). } \\
\text { Seis Ilustrações (ocupam lugar central, } \\
\text { entretanto estão no entorno da } \\
\text { fotografia. }\end{array}$ & $\begin{array}{l}\text { Uma fotografia no centro da imagem com uma figura } \\
\text { humana; seis ilustrações de figuras humanas; uma } \\
\text { ilustração em forma de olho; uma ilustração em forma } \\
\text { de lábios e dentes, além de confetes no contorno } \\
\text { da imagem. }\end{array}$ \\
\hline 5 & $\begin{array}{l}\text { Uma Ilustração (ocupa lugar central } \\
\text { na imagem e evidência o gênero } \\
\text { feminino). }\end{array}$ & $\begin{array}{l}\text { Uma Ilustração em posição central na imagem } \\
\text { evidenciando o gênero feminino, uma sombrinha } \\
\text { de frevo, uma ilustração em forma de lábios; uma } \\
\text { ilustração em forma de olho além de confetes no } \\
\text { contorno da ilustração. }\end{array}$ \\
\hline 6 & $\begin{array}{l}\text { Uma Fotografia (ocupa lugar central } \\
\text { no cartaz e evidencia o gênero } \\
\text { masculino e o feminino) } \\
\text { Sete Ilustrações (ocupam lugar central, } \\
\text { entretanto estão no entorno da } \\
\text { fotografia). }\end{array}$ & $\begin{array}{l}\text { Uma fotografia de } 2 \text { figuras humanas; sete ilustrações } \\
\text { de figuras humanas; um trio elétrico, uma figura com } \\
\text { formato de lábios e dentes, confetes nas bordas; uma } \\
\text { ilustração no formato de olho; duas sombrinhas de } \\
\text { frevo e um tambor. }\end{array}$ \\
\hline 7 & $\begin{array}{l}\text { Uma Ilustração (ocupa lugar central } \\
\text { na imagem, evidenciando o gênero } \\
\text { masculino). }\end{array}$ & $\begin{array}{l}\text { Uma ilustração do gênero masculino que ocupa } \\
\text { posição central na imagem; um tambor, uma ilustração } \\
\text { de olho e uma ilustração de lábios, além de confetes } \\
\text { no contorno da ilustração. }\end{array}$ \\
\hline
\end{tabular}

Fonte: Elaboração própria

Quanto aos temas e o princípio do conhecimento dos cartazes da campanha de combate a AIDS, observou-se como temas em todos os cartazes apresentados, a prevenção combinada e a prevenção de doenças. No eixo do princípio do conhecimento constata-se a identificação da promoção da saúde como principal foco dos sete cartazes apresentados. Contudo, a relação entre os gêneros nas capas das imagens apresentadas mostra a prevenção como foco unidirecional e apenas a figura feminina.

$\mathrm{Na}$ fase denotativa foram identificadas 52 ilustrações $(1,2,3,4,5,6,7)$ e 7 fotografias (1, 3, $4,6)$. As ilustrações são definidas como expressões gráficas que implicam em sentidos denotativo e conotativo de imagens que se aprofundam 
em detalhes informativos; já as fotografias são os elos documentais e afetivos que perpetuam a memória ${ }^{(10)}$. Em relação às cores do pano de fundo, foram utilizados o amarelo $(1,2,5,6)$, azul ( 4 e 7) e verde (3), enquanto que as cores do título da campanha ("VAMOS COMBINAR") foram combinações das cores azul e rosa (1, 2, 5, 6), marrom e laranja ( 4 e 7), e marrom e rosa (3). As cores mais utilizadas, portanto, foram: rosa $(1,2,3,5,6)$, azul $(1,2,5,6)$, marrom $(3,4,7)$ e laranja ( 4 e 7). Nas cores, a quantidade de rosas e azuis já reforça a tonalidade arcaica de uma cultura que evidencia a cor como símbolo de distinção entre os sexos e de apropriação à determinados gêneros.

$\mathrm{Na}$ construção de ações de educação em saúde (como as campanhas publicitárias governamentais), as fotografias têm maior poder de identificação junto às pessoas em relação aos demais tipos de imagens. Nesse sentido, esta pesquisa revela o uso da imagem como uma forma de discussão para garantir a rápida interpretação do leitor em textos (publicitários, oficiais, entretenimento).

Os dados identificados na fase conotativa foram 10 fotografias de figuras humanas (1, 3, 4, 6), 28 ilustrações de figuras não humanas (1, 2, 3, 4, 5, 6, 7), e 20 figuras não humanas (globo festivo, trio elétrico, lábios, olho, sombrinha de frevo, tambor, confetes), havendo, assim, predomínio de figuras não humanas (52) em relação às figura humanas (10). É importante ressaltar que dentre as figuras apresentadas nos cartazes, mostrou-se evidente aquelas que se relacionam mais ao gênero feminino, e representam a disparidade entre a relação saúde versus doença, cuidado versus desinformação e prevenção versus susceptibilidade às doenças, tendo em vista a baixa adesão de imagens de figuras que se aproximem do interlocutor masculino.

Nos signos linguísticos foram identificados nove elementos, dos quais oito eram frases ou termos e um era uma hashtag. Os signos mais utilizados, no entanto, foram as hashtags, pois a mesma hashtag foi utilizada sete vezes, seguida do termo "preservativo feminino" empregado quatro vezes, e a palavra "teste" que foi aplicada três vezes. Os verbos operados estavam no imperativo (use, faça, conheça) e no infinitivo (prevenir). As associações estabelecidas entre os verbos no imperativo e a expressão preservativo masculino estabelecem elo de poder ou ordem que subjugam a figura feminina ao perpetuar uma linguagem de pertença, muitas vezes, adaptada ao mundo real.

Houve, portanto, predomínio de signos linguísticos, como palavras, termos, hashtags e verbos usados de forma curta e direta. O "\#vamoscombinar" indica ideia de ação, remete a intervenções biomédicas, comportamentais e estruturais aplicadas no nível dos indivíduos e relações a que pertencem. Contudo, não exemplifica que a campanha apresenta à população diferentes métodos de prevenção do HIV e não cita quais são eles.

$\mathrm{Na}$ fase conotativa, portanto, os elementos mais utilizados foram os 39 textos de imagem (fotografias e ilustrações de figuras humanas e não humanas) em relação ao uso mais restrito de apenas 9 textos escritos (palavras, termos, hashtags e verbos). Nesse sentido, a maior carga de informações dependia dos textos de imagem e não dos textos escritos. Na fase conotativa observa-se 10 figuras humanas, 28 ilustrações de figuras humanas, e 20 figuras não humanas.

Houve prevalência de quatro figuras humanas femininas em detrimento de três masculinas. Quanto às ilustrações de figuras humanas, houveram 17 femininas e 13 masculinas. A relação das imagens com os textos denota a construção da imagem feminina como aquela que está diretamente ligada ao cuidado com a saúde ou com a fraqueza, e já deixa subentendido que as mulheres contaminam-se mais que os homens e, por isso, estariam em primeiro plano. Além disso, a cultura machista e patriarcal é ressaltada ao mostrar o distanciamento do homem com o cuidado com a saúde.

No domínio princípio do conhecimento, os cartazes foram qualificados para fins de Promoção da Saúde em todas as veiculações. Identificou-se, pelos temas observados, que a ênfase foi dada às intervenções biomédicas clássicas, 
especialmente o uso do preservativo masculino em detrimento de abordagens mais contemporâneas, como o uso da profilaxia pré (PrEP) e pós-exposição (PEP).

\section{Discussão}

Constatou-se expressiva quantidade de ilustrações de figuras humanas, pois a ilustração ou composição de mídias fora de um contexto histórico, os dados específicos acerca do evento não necessitam ser obrigatoriamente analisados e indexados ${ }^{(10)}$. Contudo, os vários sentidos conotativos que serão vistos e sentidos pelos receptores necessitam ser compreendidos e indicarem a ideia central, o que neste caso aponta apenas para as representações culturais brasileiras.

As ilustrações têm matrizes ligadas ao aspecto multicultural da sociedade brasileira. Nos planos inferiores das imagens observa-se a utilização das figuras como demonstração de diferentes culturas e do carnaval. O trio elétrico simboliza o marco dos blocos de rua. Essas figuras trazem um aporte histórico em que mostram diferentes culturas com modo único de celebrar.

Aparece em algumas imagens o personagem do Maracatu Rural. Este personagem surgiu no estado de Pernambuco onde os seus brincantes eram os cortadores de cana que tinham na sua atividade, um momento de lazer, de brincar, de expressar crenças e costumes, contidos no cotidiano e nas experiências vividas ${ }^{(11)}$. A figura da negra com roupas extravagantes simboliza o carnaval marcado pelas escolas de samba, do movimento em favor da expressão, do corpo e da ação como forma de valorização dos objetos introjetados na cultura, sem esquecer aquilo que já era previsto nas raízes do movimento, como os sambas-enredo, característicos do carnaval paulista e carioca.

O samba também representado no cartaz pela figura masculina é um ponto que reforça a musicalidade, o jeito e a expressão. O samba foi formatado no início do século XX, no Rio de Janeiro, e acabou tornando-se, por vários motivos, ponto pacífico em nossa sociedade como um dos agentes culturais que melhor representa o "ethos" brasileiro. O axé, mostrado através da figura masculina, a negra com marcas no corpo e tambor, a mulher, com vestimenta branca simbolizando a cultura baiana, é uma cultura especifica da região da Bahia, cunhada em 1987, e foi uma tentativa de identificar a música produzida originalmente em Salvador, recebendo também o nome de "música baiana". Uma etiqueta mercadológica usada para classificar uma vertente da música baiana que faz uso de uma fusão de ritmos, como caribenhos, africanos e "elétricos", numa roupagem pop-rock para se constituir como o invólucro do produto "Bahia" ${ }^{(12)}$.

E, por último, dos estilos musicais, o frevo, visibilizado pela mulher branca e com roupas específicas do traje. Também originário de Pernambuco, o frevo remete a um êxtase do movimento corpóreo em movimento que leva ao ápice da animação. Consta ainda no cartaz, uma boca com sentido do beijo liberal no carnaval e um globo atrás dos personagens, que é símbolo de festa e animação ${ }^{(13)}$.

As cores utilizadas foram: azul, roxo, verde, vermelho, rosa, amarelo, preto, laranja e branco. Cores fortes, como o roxo e o laranja, que chamam a atenção do interlocutor para o foco da campanha, foram utilizadas. A utilização do azul em "vamos" e nas frases de efeito espalhadas no cartaz lembram uma ação, um tomar iniciativa em detrimento da cor, que socialmente é conhecida como aquela que mais se adequa ao sexo masculino, assim como o verde. Já o rosa é mais delicado, próprio do espaço ao diálogo, da conversa, e da promoção de estratégias que promovam o indivíduo na perspectiva do conhecer e socializar. Essa cor remete a um estereótipo associado ao gênero feminino e representa a delicadeza ${ }^{(14)}$. Na mesma lógica, a segunda cor mais utilizada foi o azul, que também tem ligação imediata com o gênero masculino e ideias de dominação, controle e poder ${ }^{(14)}$.

As etapas da análise de imagem permitiram identificar que a cor mais utilizada foi o rosa, o texto escrito mais utilizado em hashtag foi "preservativo feminino", e os verbos utilizados estavam todos em modo imperativo. Há, portanto, 
sinais nos textos escritos e de imagem que apontam para um contexto de reforço de estereótipos de gênero feminino pelo fato da cor mais frequente no texto de imagem ter sido o rosa, que é uma cor com forte carga simbólica que se liga à ideia de feminino enquanto gênero dócil, romântico, subserviente, passivo e dominado $^{(15)}$.

Em relação a hashtag mais utilizada reportar para o preservativo feminino, ao mesmo tempo em que aponta para um aspecto de empoderamento feminino, talvez não seja a opção mais prática no contexto de uma festa de rua, pois a técnica de uso desse contraceptivo exige alguns cuidados difíceis de serem adotados fora de casa como, por exemplo, abrir o preservativo com cuidado (sem usar os dentes ou objetos cortantes e utilizar um preservativo em cada relação). O uso dos verbos no imperativo reforça a mensagem de imposição de comportamentos, condutas e atitudes padronizadas e sob o olhar do outro e não da própria mulher. Há, portanto, uma mensagem que corrobora a ideia de controle do corpo feminino, que é a forma como operam as sociedades patriarcais, machistas e misóginas ${ }^{(15-16)}$.

O discurso desenvolve-se com as formações lexicais variadas em relação à expressão do texto. Os verbos apresentam-se por meio do imperativo, lançando voz de autoridade no "use" em que a utilização da flexão verbal permite um estímulo à adesão do interlocutor. Enquanto "combinar", "prevenir" e "vir" atentam para a tomada de decisão do receptor e conta com a iniciativa de apoiar e de fazer parte da campanha proposta pelo emissor, o Ministério da Saúde ${ }^{(17)}$.

Nos temas das imagens, a análise encontrou dois focos principais: a prevenção da doença, quatro vezes, e a veiculação da informação, três vezes. O que se vê é o emissor "tematizar" a sua necessidade. Nesse aspecto, ele buscou, em diferentes bases de imagens, persuadir o interlocutor, tendo como parâmetro não apenas o tema objeto de sua pesquisa, mas vários temas correlatos sob os quais pretende-se informar a mensagem $^{(10)}$.
Nesse sentido, os temas relacionam-se à prevenção combinada pela utilização das frases "preservativo feminino", "camisinha" e "teste"; quando as informações veiculadas detêm-se ao ilustrativo, contendo a temática da campanha contra a AIDS no carnaval e na prevenção de doenças, relaciona-se ao "\#vamos combinar" e "camisinha". O cenário da mensagem direciona a combinação dos métodos contraceptivos e de diagnósticos ofertados pelo Ministério da Saúde.

As estratégias da prevenção combinada podem ser divididas em: intervenções biomédicas clássicas - que empregam métodos de barreira física ao vírus, já largamente usados no Brasil (preservativos e géis) - e as intervenções biomédicas baseadas no uso de antirretrovirais $(A R V), \operatorname{PrEP}$ e $\mathrm{PEP}^{(18)}$. Essas intervenções serão pontos estratégicos de ajuda e atendimento tanto para a prevenção como para a contenção da doença, uma rede integrada e participativa ${ }^{(18)}$.

A promoção da saúde é uma estratégia do setor de saúde que reitera os princípios do SUS, integrando-se na luta para a construção de um modelo de atenção à saúde pública, universal e integral, equitativo e de qualidade, pautado pelo investimento em sujeitos autônomos e solidários, que aprofunde a gestão democrática dos serviços de saúde e fortaleça estratégias intersetoriais de melhoria da qualidade de vida da população $^{(19-20)}$.

Ao reiterar os princípios do SUS, a promoção da saúde retoma a integralidade, a equidade e a universalidade. Nesse aspecto, a campanha tem cunho verticalizado, prescritivo de comunicação, pois utiliza verbos no imperativo e com o sentido de ordem. Dessa forma, impacta negativamente o interlocutor e fere a autonomia do indivíduo, pois é nessa configuração que se entende a relação de dominante e dominado, à qual a população não costuma se subjugar.

Dessa forma, os conteúdos da campanha deveriam promover saúde com base na perspectiva da equidade de gêneros, enfatizando a corresponsabilidade de ambos os gêneros. Entretanto, o que se observa, é uma mensagem que aponta para a responsabilização maior do corpo feminino diante das práticas sexuais, o que pode 
tornar o carnaval, em vez de um divertimento, em mais um espaço de controle do corpo e excesso de responsabilidade da mulher.

Nos campos da saúde, a universalidade aos serviços ocorre pela promoção e a capacidade do indivíduo entrar em contato com os níveis de atenção que precisa. Contudo, a subjetividade dos gêneros com relação ao cuidar não está relacionado apenas ao acesso, mas também à garantia de seus direitos, sem repressões históricas vivenciados pelos corpos sexuados e pela longitudinalidade de uma diferença desigual que é perpetuada também nas imagens de campanhas carnavalescas.

A continuidade de acesso nos diferentes níveis de atenção com a resolutividade ou o tratamento de suas comorbidades é um direito de todo cidadão, previsto pelo princípio basilar do SUS, que é a integralidade. Essa continuidade perpassa o conceito de gênero, principalmente por perceber-se como elemento constitutivo das relações humanas, acima de tudo histórico, pois as mulheres foram cerceadas de seus direitos por muito tempo e dentre eles a saúde. O gênero é uma questão em aberto que não se limita ao que o masculino ou o feminino intervém ou propõe, mas uma tentativa de coletivizar uma fantasia que tem como fim a estrutura familiar ${ }^{(21-22)}$.

Além de não persuadir de forma reflexiva e positiva, a campanha esboça apenas a informação de forma imprecisa sobre a prevenção, e na forma subjetiva do entendimento, constrói uma visão hierarquizada que corrobora a intimidação e a não adesão às práticas de prevenção combinada. Não é, desse modo, o sexo que determina os gêneros, mas este constitui a chave para interpretar, de fato, uma consciência não normativa da realidade ${ }^{(21)}$.

O estudo apresentou limitações quanto à disponibilidade das imagens veiculadas na campanha de carnaval pelos meios oficiais do governo. A pesquisa contribui com a ciência ao identificar sobreposição dos gêneros nos cartazes das campanhas e, principalmente, resgatar o foco da tomada de decisão, que não se centraliza apenas nos preservativos, já que existem outros métodos de prevenção contra o vírus do HIV e que não são contemplados nas mídias sociais, desfavorecendo o processo de educação em saúde.

\section{Conclusão}

Os símbolos são utilizados no cartaz como forma de alusão à prevenção da AIDS. A utilização de ilustrações e fotografias levam a um contexto aproximado da realidade, entretanto, isso implica nas formas e condutas que esta atitude necessita. É observado na fotografia o acolhimento e a visibilidade do método contraceptivo, contudo ainda gera insegurança e receio por parte da população que não veem medidas efetivas de proteção ou simulam uma realidade distante da doença, além de conhecimento deficiente transmitido pela expressão facial no rosto das figuras humanas com foco no preservativo feminino.

A utilização do trio elétrico, congado, maracatu rural, sambistas, baianos e do frevo revelam o respeito e as afirmativas acerca do aporte histórico e cultural que o Brasil contém. Afirma, portanto, as matrizes carnavalescas e dão testemunho dessa relação eficaz até os dias atuais. A campanha lança o apelo "vamos combinar", que além de ser uma iniciativa ministerial é um pedido de atenção ao diálogo entre os partícipes da relação, e se cunha nas formas biomédicas de prevenção já divulgadas pelo governo. Por outro lado, o sentido denotativo imperativo do "use sempre camisinha e conheça todas as formas de prevenção ao HIV", remete a um espaço de ordem em que não se constitui outras formas preventivas em destaque no cartaz e impõe voz aos subordinados (interlocutores) para a prevenção.

O cartaz ainda chama a atenção para a tomada de decisão do interlocutor. As minorias sexuais, que possuem vulnerabilidades em relação à exposição ao vírus, não são contempladas no cartaz, passando a acreditar que não existem públicos socialmente vulneráveis, quando, na verdade, é a população mais atingida pela contaminação. 
Além disto, as cores mais utilizadas reforçam estereótipos de gênero pautados numa visão dicotômica e machista o que pode comprometer o processo de educação em saúde que é, em suma, o objetivo de toda campanha educativa governamental.

Conclui-se que existe uma ambiguidade de discursos em que coexistem uma linguagem horizontalizada embasada na estratégia da prevenção combinada e uma linguagem verticalizada expressa nos verbos no imperativo.

\section{Colaborações:}

1 - concepção, projeto, análise e interpretação dos dados: João Cruz Neto e Joseph Dimas de Oliveira;

2 - redação do artigo e revisão crítica relevante do conteúdo intelectual: João Cruz Neto e Joseph Dimas de Oliveira;

3 - aprovação final da versão a ser publicada: João Cruz Neto e Joseph Dimas de Oliveira.

\section{Referências}

1. Brasil. Ministério da Saúde. Secretaria de Vigilância em Saúde. Boletim epidemiológico de HIV/AIDS 2019 [Internet]. Brasília (DF); 2019 [cited 2020 Jul 20]. Available from: http://www.aids.gov.br/pt-br/pub/2019/ boletim-epidemiologico-de-hivaids-2019

2. Vianna CP. O movimento LGBTI e as políticas de educação de gênero e diversidade sexual: perdas, ganhos e desafios. Educ Pesqui, São Paulo. 2015;41(3):791-806. DOI: https://doi.org/10.1590/ s1517-97022015031914

3. Gomes R, Murta D, Facchini R, MeneghelSN. Gênero, direitos sexuais e suas implicações na saúde. Ciênc saúde coletiva. 2018;23(6):1997-2006. DOI: http:// dx.doi.org/10.1590/1413-81232018236.04872018

4. Penn G. Análise Semiótica de Imagens Paradas. In: Bauer MW, Gaskell G, organizadores. Pesquisa qualitativa com texto, imagem e som: um manual prático. 2a ed. Petrópolis: Vozes; 2008.

5. Greco DB. Trinta anos de enfrentamento à epidemia da Aids no Brasil, 1985-2015. Ciênc saúde coletiva. 2016;21(5):1553-64. DOI: https:// doi.org/10.1590/1413-81232015215.04402016
6. Dourado I, MacCarthy S, Reddy M, Calazans G, Gruskin S. Revisitando o uso do preservativo no Brasil. Rev bras epidemiol. 2015;18(Suppl 1):63-88. DOI: https://doi.org/10.1590/1809-4503201500050006.

7. Brasil. Ministério da Saúde. Secretaria de Vigilância em Saúde. Boletim epidemiológico HIV/AIDS 2017 [Internet]. Brasília (DF); 2017 [cited 2019 Aug 7]. Available from: http://www.aids.gov.br/ pt-br/pub/2017/boletim-epidemiologico-hivaids2017

8. Brasil. Ministério da Saúde. Prevenção Combinada do HIV - Bases conceituais para profissionais, trabalhadores(as) e gestores(as) de saúde [Internet]. Brasília (DF); 2017 [cited 2019 Aug 10]. Available from: http://www.aids.gov.br/pt-br/pub/2017/ prevencao-combinada-do-hiv-bases-conceituaispara-profissionais-trabalhadoresas-e-gestores

9. Hipolito RL, Oliveira DC, Costa TL, Marques SC, Pereira RE, Gomes AMT. Quality of life of people living with HIV/AIDS: temporal, socio-demographic and perceived health relationship. Rev Latino-Am Enfermagem. 2017;25:e2874. DOI: http://dx.doi.org/10.1590/ $1518-8345.1258 .2874$

10. Rodrigues RC. Análise e tematização da imagem fotográfica. Ci inf. 2007;36(3):67-76. DOI: https:// doi.org/10.1590/S0100-19652007000300008

11. Santos EC, Helal DH. Maracatu, Trabalho e Organizing. Rev adm contemp. 2018;22(4):620-38. DOI: http://dx.doi.org/10.1590/1982-7849rac2018170086

12. Jost M. A construção/invenção do samba: mediações e interações estratégicas. Rev Inst Estud Bras. 2015;62:112-25. DOI: https://doi.org/10. 11606/issn.2316-901X.v0i62p112-125

13. Bueno LAP, Sousa CC, Sousa CC, Silva DC, Lhenen GC, Pires GS, et al. Manifestação popular brasileira: frevo aplicado aos movimentos In: Ação de extensão e cultura. São Paulo (SP): Sociedade Brasileira para o Progresso da Ciência; 2015. p. 1-5 [cited 2019 Aug 7]. Available from: http://www.sbpcnet.org.br/livro/63ra/conpeex/ extensao-cultura/trabalhos-extensao-cultura/ extensao-cultura-leticia-amorim.pdf

14. Oliveira JF. Vibrando na cor rosa [editorial]. Rev baiana enferm. 2014;28(2):116. DOI: http://dx.doi. org/10.18471/rbe.v27i2.12338

15. Oliveira-Cruz MF. Representações do feminino na publicidade: estereótipos, rupturas e deslizes [monografia na Internet]. Chasqui: Rev Latin Comunicación; 2017 [cited 2020 Sep 4];134:181-200. 
Available from: https://dialnet.unirioja.es/servlet/ articulo?codigo $=5974561$

16. Guimarães MC, Pedroza RLS. Violência contra a Mulher: problematizando definições teóricas, filosóficas e jurídicas. Psicol soc. 2015;27(2):256-66. DOI: http://dx.doi.org/10.1590/1807-03102015v $27 \mathrm{n} 2 \mathrm{p} 256$

17. David RS. Análise semiótica: campanha publicitária do Ministério da Saúde no combate à dengue. Scientia Tec [Internet]. 2017 [cited 2019 Aug 10];4(1):60-71. DOI: https://doi.org/10.35819/ scientiatec.v4i1.1681

18. Gomes ESS, Galindo WCM. Equipes de saúde da família frente à testagem e ao aconselhamento das IST, HIV-AIDS. Rev baiana saúde pública. 2018;41(3):628-49. DOI: https://doi.org/10.22278/ 2318-2660.2017.v41.n3.a2376

19. Malta DC, Reis AAC, Jaime PC, Morais Neto OL, Silva MMA, Akerman M. O SUS e a Política
Nacional de Promoção da Saúde: perspectiva resultados, avanços e desafios em tempos de crise. Ciênc saúde coletiva. 2018;23(6):1799-809. DOI: http://dx.doi.org/10.1590/1413-81232018236. 04782018

20. Prado NMBL, Santos AM. Promoção da saúde na Atenção Primária à Saúde: sistematização de desafios e estratégias intersetoriais. Saúde debate. 2018;42(spe 1):379-95. DOI: http://dx.doi. org/10.1590/0103-11042018s126

21. Scott JW. Gender: still a useful category of analysis? Diogenes. 2010;57(1):7-14. DOI: 10.1177/ 0392192110369316

22. Gomes CM. Gênero como categoria de análise decolonial. Civitas. 2018;18(1):65-82. DOI: http:// dx.doi.org/10.15448/1984-7289.2018.1.28209

Recebido: 3 de agosto de 2020 Aprovado: 7 de setembro de 2020 Publicado: 13 de outubro de 2020

A Revista Baiana de Enfermagem utiliza a Licença Creative Commons - Atribuição-NãoComercial 4.0 Internacional. https://creativecommons.org/licenses/by-nc/4.0/ Este artigo é de acesso aberto distribuído sob os termos da Licença Creative Commons (CC BY-NC). Esta licença permite que outros remixem, adaptem e criem a partir do seu trabalho para fins não comerciais. Embora os novos trabalhos tenham de lhe atribuir o devido crédito e não possam ser usados para fins comerciais, os usuários não têm de licenciar esses trabalhos derivados sob os mesmos termos. 